Article

\title{
Trans Laws and Constitutional Rulings in Belgium: The Ambiguous Relations between Sex and Gender
}

\author{
Petra Meier ${ }^{1, *}$ and Joz Motmans ${ }^{2,3}$ \\ ${ }^{1}$ Department of Political Science, University of Antwerp, 2000 Antwerp, Belgium; E-Mail: petra.meier@uantwerpen.be \\ 2 Transgender Infopunt, Ghent University Hospital, 9000 Ghent, Belgium; E-Mail: joz.motmans@uzgent.be \\ ${ }^{3}$ Centre for Research on Culture and Gender, Ghent University, 9000 Ghent, Belgium \\ * Corresponding author
}

Submitted: 30 January 2020 | Accepted: 15 August 2020 | Published: 18 September 2020

\begin{abstract}
In this article we reflect upon the evolution from the Belgian trans law of 2007 to those of 2017 and beyond, giving adult citizens the possibility to have their self-determined gender legally recognised. The 2019 ruling of the Belgian Constitutional Court, condemning the Belgian State for being discriminatory against gender fluid and gender non-binary persons regarding their legal gender recognition, requires the Belgian government to either add a third legal option or to abolish gender registration altogether. We analyse the definitions of sex and gender that underlie the two trans laws of 2007 and 2017 and the Constitutional Court ruling of 2019 and then confront them with the experiences of trans people based on a national transgender survey (Motmans, Wyverkens, \& Defreyne, 2017). The confrontation between legal texts and lived experiences clearly shows the promises and pitfalls states face when striving for gender recognition procedures.
\end{abstract}

\section{Keywords}

Belgium; gender; law; recognition; sex; transgender

\section{Issue}

This article is part of the issue "Trans* Politics: Current Challenges and Contestations" edited by Mieke Verloo (Radboud University, The Netherlands) and Anna van der Vleuten (Radboud University, The Netherlands).

(C) 2020 by the authors; licensee Cogitatio (Lisbon, Portugal). This article is licensed under a Creative Commons Attribution 4.0 International License (CC BY).

\section{Introduction}

In 2007, after ample discussion, Belgium adopted its first trans law, thus joining the growing list of European countries recognizing trans persons (Motmans, 2011). After the regulation of important issues for lesbian, gay, and bisexual persons some years before, such as same-sex marriage, reproduction and adoption rights, inheritance rights, and anti-discrimination provisions (Eeckhout \& Paternotte, 2011; Meier, 2009), it was now the turn for trans people to see their needs and interests taken into account. A decade later, in 2017, a new trans law was voted in, as the first one had been criticised for approaching trans people in a very paternalistic, medicalised, and gender binary way (Motmans, de Biolley, \& Debunne, 2010; Senaeve \& Uytterhoeven, 2008). The trans law of 2017 dropped the medically binary construct of persons, further disentangled gender and sex, and based the application procedure on self-determination. Notwithstanding this new approach, the LGBTIQ+ organizations Çavaria, Genres Pluriels, and RainbowHouse filed a complaint at the Belgian Constitutional Court for the exclusion of any provision for non-binary or gender fluid people (Cannoot, 2019a). In 2019, the Belgian Constitutional Court ruled that the trans law of 2017 was indeed discriminatory for gender fluid and gender nonbinary people, and the corresponding paragraphs need to be deleted (Cannoot, 2019b).

Different states are more and more confronted with the obligation to recognize the "emergence of a right to gender identity.... which gives every individual the right to recognition of their gender identity and the right to be treated and identified according to this identity" (Parliamentary Assembly, 2015). The European Court of 
Human Rights (ECHR) has held that national legislation must render the rights under the ECHR "practical and effective, not theoretical and illusory" (Christine Goodwin $v$. the United Kingdom, 2002). In this article, we examine how the Belgian state is struggling with the registration of sex whilst acknowledging the existence of multiple genders and highlight the inherent tension states face when recognizing gender diversity whilst also clinging to sex registration systems. We first describe the evolution of the legal-and thus institutional(ized)-thinking regarding who is to be considered a trans person, and what ideological frames of sex and gender underlie this thinking, by exploring the two trans laws of 2007 and 2017 and the Constitutional Court ruling of 2019. We then explore the experiences of trans people based on a national transgender survey (Motmans et al., 2017), analysing their personal positions in the sex/gender realm, and the impact thereof on legal gender provisions. In the conclusion, we combine the sex/gender discourses within the legal framework with the lived experiences of trans people and extrapolate what the Belgian case teaches states striving for gender recognition procedures.

Since language has performative power and thus impact (Arcelus \& Bouman, 2017; Bouman et al., 2017) and since appropriate language is important, we use 'trans' as an umbrella term to refer to a broad spectrum of possible gender identities which may include: people living with or without gender dysphoria; those not searching for a social and/or medical transition; those making a social transition only, without medical needs; and/or gender-nonconforming people (Defreyne, Motmans, \& T'Sjoen, 2017). We will, however, use 'transsexuals' or 'transgender persons' or 'gender non-binary persons' when citing legal texts to illustrate the changes in wordings, or when respondents chose that identity label for themselves. It is also important to notice that in both Dutch and French, sex and gender are two distinct words, and legal texts most often use 'sex' to refer to the sex assigned at birth, which, in Belgium, is limited to male or female options only.

\section{Sex, Gender and the Belgian Laws on Gender Registration}

\subsection{Sex and Gender Diversity}

The disentanglement of, or difference between, the sex assigned at birth which is legally recorded, and the gender identity of a person has been a topic of debate both academically and politically for decades. Gender identity is nowadays defined as the psychological identification of oneself, or an internal sense of being, in relation to gender (Arcelus \& Bouman, 2017). Currently, it is understood that some people have a gender which is neither male nor female and may identify as both male and female at the same time, as different genders at different times, as no gender at all, or dispute the very idea of there only being two genders (Motmans, Nieder, \& Bouman, 2019).
More recently, quantitative surveys have started to capture the inherent diversity of gender experiences, acknowledging gender diversity besides (legal/medical) binary sex systems. Recent research shows that in Flanders, the Dutch-speaking part of Belgium, around $0.7 \%$ of people registered as male at birth and $0.6 \%$ of people registered as female at birth identify more with the 'opposite' sex than their birth sex (Van Caenegem et al., 2015). In addition, around $2.2 \%$ of people registered as male at birth and $1.9 \%$ of people registered as female at birth identify as much or as little with the 'opposite' sex. Extrapolated to Belgium, around 134,000 people could be categorized as transgender or gender non-binary in a population of about 11 million. In a recent overview of measurements for gender identity used by state registers and population surveys, Motmans, Burgwal, and Dierckx (2020) found in Dutch and Belgian non-trans specific surveys that the proportion of people identifying outside the expected gender, as registered at birth, varies between $1.6 \%$ when categorical questions (closed list of identity options) are used, and up to $6.7 \%$ when 5 pointLikert scales are used. In a recent review focusing on higher-quality data, Zhang et al. (2020) analysed recent studies (published 2009-2019) assessing the proportion of trans and gender diverse (TGD) people in the general population, and found that the proportions of individuals with a TGD-relevant diagnosis or other recorded evidence ranged between 17 and 33 per 100,000 enrolees. The authors also found that, when the surveys specifically inquired about 'transgender' identity, the estimates ranged from $0.3 \%$ to $0.5 \%$ among adults, and from $1.2 \%$ to $2.7 \%$ among children and adolescents. When the definition was expanded to include broader manifestations of 'gender diversity,' the corresponding proportions increased to $0.5-4.5 \%$ among adults and $2.5-8.4 \%$ among children and adolescents (Zhang et al., 2020).

Many scholars and activists have highlighted how the confrontation with (binary) legal sex registration systems worldwide has led to many trans-identified citizens not being able to be recognized in their gender (Cannoot, 2019c; Hines, 2009; Parliamentary Assembly, 2015). In the following paragraphs, we analyse in detail what the Belgian state has put in place in this field.

\subsection{The Belgian Registration Systems and Laws}

\subsubsection{The 2007 Trans Law}

Prior to 2007, trans people could only get their first name changed through a Ministerial Decree and by having the sex marker on their birth certificates changed by a court. There were also regional differences in implementation: Dutch-speaking actors mainly held that an application for a change of status needed to be filed, whereas Frenchspeaking colleagues defended an application to amend the civil status documents. The procedure and legal consequences of both positions differ, as does the line of thought underlying them. The first position emphasized 
observable morphological criteria; the second, personal appreciation (Motmans et al., 2010). The trans law of 10 May 2007 (Belgian Official Journal, 2007) was meant to guarantee trans people a number of the same rights across the country (see Motmans et al., 2010, for an analysis of this process).

This trans law offered trans people the right to officially change the registration of first name(s) and sex in accordance with recommendation 1117 of the Council of Europe (Parliamentary Assembly, 1989). The title of the law-Law Concerning Transsexuals-well described the target group: individuals whose gender identity was the opposite of their assigned sex, and who would undergo gender reassignment surgery. The existing administrative procedure was upheld and extended to transsexuals at one-tenth of the usual cost. Individuals could file an application which needed to be accompanied by a statement by their psychiatrist and endocrinologist. The latter had to declare that:

i) The individual showcased a constant and irreversible inner conviction of belonging to the sex other than the one stated on their birth certificate; ii) the individual was undergoing or had undergone hormone replacement therapy to induce the physical gender characteristics of the sex to which the individual in question believed to belong to; and iii) the change of first name was an essential feature of the change of gender role. (Belgian Official Journal, 2007)

The court procedure to change the registration of birth sex was replaced by an administrative procedure at the civil registry (Senaeve \& Uytterhoeven, 2008) and was subject to several cumulative conditions. A person wanting to change the sex marker on their birth certificate and identity card, legally needed to demonstrate this to the registrar by presenting a statement from the psychiatrist and surgeon declaring, next to point i) mentioned in the previous quote, that:

ii) The individual had undergone sex reassignment so as to make her/him correspond with the other sex to which the individual in question was convinced to belong to; and iii) the individual was no longer capable of producing children in accordance with her/his original assigned birth sex. (Belgian Official Journal, 2007)

To be recognised as male, one needed to undergo the removal of the ovaries, to be recognised as female, one needed to undergo the removal of testes (Belgian Official Journal, 2017b). Genital reconstruction surgery was not compulsory although the trans law was often read that way (Motmans, 2011). The registrar was to check the legal conditions regarding the application but would not conduct any discretionary physical checks relating to the sex reassignment. As civil marriage and adoption had been opened to same-sex couples in 2003 and 2006, respectively, married trans people no longer needed to di- vorce before being able to change their birth certificate. Family members were no longer given one month to object the application (Motmans, 2011). After the trans law came into force, a slight increase in the number of applications for legal gender recognition was noted (Van Hove, 2019).

\subsubsection{The 2017 Trans Law}

The 2017 trans law (Belgian Official Journal, 2017a) changed the established rules in three ways (Verschelden, 2020): An adaptation of the registration of one's sex on the birth certificate no longer required medical intervention such as gonadectomy (removal of the gonads, testes or ovaries) or hormonal replacement therapy; the application is now based on a simple declaration filed by the applicant; and minors only need the approval of both parents alongside a statement from a youth psychiatrist declaring that they are capable of making such a decision. In the absence of parental approval, the applicant can apply for a guardian ad hoc through a civil court (Verschelden, 2020). In case of no negative advice by the public prosecutor, the procedure is continued.

A second new rule concerns the loosening up of the conditions to change one's first name. Again, all medical conditions were dropped, and self-determination was put centre stage (Verschelden, 2020). Declaring that the sex mentioned on the birth certificate does not correspond to an individual's inner gender identity suffices for them to benefit from the preferential tariff for trans people to change their first name. Also, the legal age for applying for first name changes was dropped to 12 years, but minors need parental consent of both parents unless the parental authority has been issued to only one of them. Subsequent changes of first name are possible but fall under the regular law of 15 May 1987 regarding names and the full tariff applies. An exception is again made for minors, to allow for the ongoing evolution of their gender identity.

Finally, a third new rule targets parental linkages. In some cases, adoption of the biological child was the only venue available to a trans woman to establish parenthood bonds, similar to what lesbian couples did (Verschelden, 2020) prior to the 2014 law on co-mothers (Belgian Official Journal, 2014). Trans men with a female partner who had given birth to a child could recognize their child by simple declaration, as all fathers of children born outside a legal marriage, but could not be recognised as male and then give birth, due to the requirement of infertility. According to the new rules, parentage bonds with children born before the registration of a change of sex marker do not alter. For children born after the registration of a change of sex marker, the rules stipulate that trans fathers giving birth to a child are legally recognized as being the mother, and trans women conceiving a child (with their or donor sperm) are recognized as being the father but are mentioned on the birth certifi- 
cate of that child as co-mother. Parenthood linkages are adapted in case of the re-registration of the sex marker to the original sex (Cannoot, 2019b; Verschelden, 2020).

\subsubsection{The 2019 Constitutional Court Ruling}

The trans law of 2017 dropped the medically founded binary construct of persons, further disentangled gender and sex, and based the application procedure on self-determination. It was followed by a huge increase in applications for changing gender registration. Data from the federal Institute for the Equality of Women and Men on the number of people who registered a change in gender registration show how the new trans law gave rise to as many changes during the previous two years (2018-2019) as over the previous 25 (Van Hove, 2019). Notwithstanding these accomplishments, soon after the trans law was published in the Belgian Official Journal, three major LGBTIQ+ organizations, Çavaria, Genres Pluriels, and RainbowHouse, issued a partial annihilation request to the Belgian Constitutional Court. They argued that the inherent non-fluid character of the trans law and the lack of a third gender option discriminate against gender non-binary and gender fluid people (Junes, 2018; Verschelden, 2018). In 2019, the Belgian Constitutional Court ruled that the trans law of 2017 is indeed discriminatory for gender fluid and gender nonbinary people and that the corresponding paragraphs needed to be deleted (Belgian Official Journal, 2020; Cannoot, 2019b). The Constitutional Court ruled that applicants should be able to change their gender registration more than once using the same simple administrative procedure, hinting at a recognition of gender fluidity. Second, it ruled that the government has to find a way to legally recognize gender non-binary persons, either by adding a third legal gender besides 'male' and 'female,' or by abolishing the system of gender registration altogether (Belgian Official Journal, 2020).

A proposal addressing the first part of the ruling, and deleting the corresponding paragraphs, has been submitted in parliament early 2020 and is expected to pass without much debate. The second part of the ruling, dealing with how to accommodate gender non-binary persons, is more challenging and might take several rounds of parliamentary debate. The Constitutional Court ruling as such leaves how to handle the issue up to the government.

\subsection{The Relation between Sex and Gender in the Belgian Registration Systems and Laws}

Whereas the stipulations of the 2007 trans law reflected a rather conservative stance on trans-actually genderissues, the 2017 trans law reflects an important paradigmatic shift in how birth sex and gender identity relate to each other, thereby opening the path for a non-binary definition. The 2019 Constitutional Court ruling was interesting as it sets a non-binary and gender fluid definition in stone.
The strict medical criteria put forward in the 2007 trans law, both for a change of registration of sex marker and for a change of first name, reflect a strict binary understanding of sex and its full conflation with the concept of gender. The legal criteria inherent in the 2007 trans law were defined in such a way that one could be either man or woman, whereby inward and outward physical features had to meet the traditional definition of sex, and one had to be "medically reassigned" to the extent possible. Physical features then had to correspond to a stable and fixed male or female gender identity, and its assumed associated expression, asking the applicant "to take on the associated gender role." The most clear-cut illustration of this line of thought is the condition of an irreversible form of infertility so as to ensure that either sex would not be able to contribute to a form of reproduction contrary to what had been defined as biologically natural, whereby men conceive and women give birth (Motmans, 2011). Being a trans person in Belgium, in the period 2007-2017, meant that one belonged to the other sex than that assigned at birth. It was an issue of a transition from one side of the spectrum to the other, whereby sex and gender were-in legal terms-seen as congruent. Although other gender identities and gender fluidity were possible, these could not be expressed in any legal terms or be subject to any formal recognition or protection. The 2007 trans law thus left out a large group of trans people whose sex and gender did not neatly align, and/or who did not wish, or were unable for personal, social, financial, medical, or any other reason, to go through all the stages of the treatment process to move from one side of the binary construct to the other. Furthermore, the 2007 trans law was gender blind, in the sense that is was influenced by the rather simple medical pathway of trans women only, leaving out the medically more complicated pathway of trans men, and ignoring the existence of gender fluid and non-binary people.

In comparison to the 2007 trans law, its 2017 successor makes an opening for the disentanglement of sex and gender. Whereas the 2007 trans law is based on sex and ignores gender, its 2017 successor allows for people's gender identity to be recognised but registers it as if it is their sex. By dropping the medical conditions and the statements on behalf of a psychiatrist, endocrinologist, or surgeon in order to change first name and registration of sex on the birth certificate, the 2017 trans law allows for a variety of combinations of sex markers, gender identities, and bodily features. First, we notice a more nuanced approach to an understanding of gender identity. Applicants no longer have to state they have the "permanent and irreversible conviction of belonging to another sex than the one stated on their birth certificate," and "had taken on the corresponding gender role," (Belgian Official Journal, 2017a) but simply that their inner feelings of gender identity do not correspond to the official sex marker on their birth certificate, and that they wish to change this marker. In doing so, it acknowledges that the inner feeling of gender identity is 
authentic, personal, and valid, and cannot be fully captured in female/male understandings. However, the legal sex markers are still restricted to either female or male. As such, one can read that what the state registers as a sex marker is in fact more a proxy of the lived gender identity. The 2017 trans law has mainly been praised for the degree of self-determination when it comes to defining gender, which opens the door to a more disentangled approach to sex and gender. Being a trans person no longer by definition involves a (medical) transition from one side of the binary spectrum to the other, but any possible combination of sex and gender. Secondly, the 2017 trans law shows that policymakers accepted the fact that bodily characteristics do not equal gender identity, and that modifying bodily characteristics is not an option for nor a wish of many of those who identify as trans. Insights from studies such as the national transgender survey (Motmans et al., 2017) informed politicians about the proportion of self-identified trans people who do not wish to or cannot access medical provisions, and thus are unable to fulfil the medical criteria in the law. Being deprived of access to legal recognition was understood as an extra unnecessary burden to be removed. Whereas the first trans law was largely inspired by experiences of trans women who at that time were more visible and vocal and who chose to a larger extend to remove their gonads (Motmans, 2011), the more recent trans law was inspired by the expertise of a variety of stakeholders.

Nonetheless, the trans law of 2017 still contains a dual notion of sex, a linear understanding of a gender transition from one gender to another, and the idea of transitioning as a once-in-a-lifetime change. First, the 2017 trans law opens the possibility for a non-binary definition of gender identity, but only at the level of one's personal discretion, as there is no legal option for a third sex/gender or for not choosing any sex/gender. Second, the trans law expects trans people to want to adopt the first name early on, and later the sex marker, and requires that the new name fits the assumed gender. The age differences (12 for a change of first name, 16 for the change of gender marker) were largely inspired by a medical understanding of gender awareness (arising around the age of 12), and the age of the start of genderaffirming hormonal treatment (at the age of 16). Starting gender-affirming hormonal treatment (testosterone for trans men, oestrogens for trans women) is clearly understood as an indication of 'knowing for sure,' and as an indication that there will be 'no way back,' so it is 'safe' to grant these youngsters the legal possibility of changing their sex marker. The additional requirement of attestation by a youth psychiatrist for those aged 16 or 17 added even more guarantees for those who might oppose the law. The need for the involvement of youth psychiatrists was argued against by the youth psychiatrists of the Belgian youth gender team during the parliamentary hearing in 2016 (Belgian Chamber of Representatives, 2016), as it violates the 2015 statement of the World Professional Association for Transgender
Health on Identity Recognition (2015). However, this was not considered. Third, a change of sex marker on the birth certificate and of first name is in principle meant to take place just once. Minors can 'make a mistake,' by giving them a second chance to change their name back again before they turn 18 . Requests by adults to annul a change in registration of sex or first name need to be taken to the family court; such a request is only possible under exceptional circumstances. So far, only one case is known where such a change was asked for and granted.

In short, while the 2017 trans law allows for a multitude of combinations of sex and gender identities, and thus gender fluidity in that respect, it does not leave room for a legally recognized gender fluidity whereby individuals could shift, even constantly shift, their gender identity and make use of more than two options. In that sense, gender identity is not understood as fluid but as a linear development: as being fixed at a certain given age. In this light, the legal provisions can be read as if the façade still must fit a traditional logic, no matter what gender identity/ies a person experiences and what physical features he/she/they carry. It is here that the relevance of the 2019 Constitutional Court ruling comes in. This ruling breaches the gender binary categorization and acknowledges the need to legally recognise gender non-binary as well as gender fluidity. This need was already voiced by the LGBTIQ+ organisations during the parliament hearing in 2016 (Belgian Chamber of Representatives, 2016) but the addition of a third gender category had been a political bridge too far in 2017, let alone the idea of an annulation of the system of birth sex registration altogether (Verschelden, 2018). However, a first glance into the Eurobarometer on Discrimination (European Commission, 2019, p. 4) shows that, on average, in Belgium $54 \%$ of the population agrees that public documents, such as passports and birth certificates, should contain a third option like $\mathrm{X}$ or $\mathrm{O}$ (other) for those who do not identify as female or male.

\section{Experiences of Gender Non-Binary People}

When the trans law of 2017 was adopted, an online anonymous survey which assessed everyday life experiences of trans people in Belgium was set up by the authors, in extensive cooperation with a variety of trans organisations. Commissioned by the Federal Institute for the Equality of Women and Men (Motmans et al., 2017), ethical approval was requested and obtained from Ghent University Hospital Ethics Committee (EC 2017/0599). The survey covered a broad range of issues such as health status, experiences in school, at work, with public administration, and legal recognition (Motmans et al., 2017). Respondents who self-identified as trans (including a broad range of possible gender identities) could take part in a Dutch, French, or English version of the survey. The data were collected before the 2017 trans law took force (January 2018), but after its adoption by 
the government and subsequent media coverage. In total, 534 self-identified trans respondents aged 16 years or older and living in Belgium took part, the largest trans sample ever collected in Belgium.

For the purpose of this contribution, we will focus on the data regarding gender identity preferences, experiences, and views on the topic of legal gender recognition, so as to understand what the options suggested by the Belgian Constitutional Court's ruling (adding a third legal option or abolishing gender registration altogether) would solve for trans people.

\subsection{Gender Identities and Their Relation to Registered Sex at Birth}

All respondents were first offered a list of possible identity labels to choose from (multiple answers were possible). Second, we asked them to choose one option out of a closed list of possible answers ('trans men,' 'trans woman,' 'gender non-binary person,' 'crossdresser,' or
'I don't know/l don't have a preference'). This empowered respondent to decide in which group they would be categorised for the analysis of the data.

$22 \%(n=117)$ of the respondents chose the gender non-binary option, $26 \%(n=141)$ chose 'trans men,' $48 \%$ ( $n=256)$ 'trans women,' and $4 \%(n=20)$ 'cross-dresser' (see Table 1). These numbers already show the potential amount of trans people (namely 26\%) who do not fit neatly into legal categories of male or female and indicate how gender identity is broader than these two categories. In addition, we noted that 250 respondents (46.8\% of the total sample) chose more than one option. Furthermore, when looking in detail at the combination of the binary (trans men, trans woman, or crossdresser) versus non-binary groups with the list of identity labels they could choose from, we see that $13 \%$ of all 'binary' respondents also chose a non-binary identity option (genderqueer, non-binary, polygender, genderfluid). And $46.2 \%$ in the non-binary group also identify with a 'binary' identity label (man, woman, trans man, man with

Table 1. Gender identity labels by binary and non-binary respondents.

\begin{tabular}{|c|c|c|c|c|}
\hline & & Binary & Non-binary & Total \\
\hline \multirow[t]{2}{*}{ Man } & $\mathrm{N}$ & 80 & 10 & 90 \\
\hline & $\%$ & $19.2 \%$ & $8.5 \%$ & \\
\hline \multirow[t]{2}{*}{ Woman } & $\mathrm{N}$ & 147 & 15 & 162 \\
\hline & $\%$ & $35.3 \%$ & $12.8 \%$ & \\
\hline \multirow[t]{2}{*}{ Man with a transgender past } & $\mathrm{N}$ & 27 & 2 & 29 \\
\hline & $\%$ & $6.5 \%$ & $1.7 \%$ & \\
\hline \multirow[t]{2}{*}{ Woman with a transgender past } & $\mathrm{n}$ & 47 & 0 & 47 \\
\hline & $\%$ & $11.3 \%$ & $0.0 \%$ & \\
\hline \multirow[t]{2}{*}{ A cross-dressing man } & $\mathrm{n}$ & 22 & 6 & 28 \\
\hline & $\%$ & $5.3 \%$ & $5.1 \%$ & \\
\hline \multirow[t]{2}{*}{ A cross-dressing woman } & $\mathrm{n}$ & 1 & 1 & 2 \\
\hline & $\%$ & $0.2 \%$ & $0.9 \%$ & \\
\hline \multirow{2}{*}{$\begin{array}{l}\text { A trans man: a person who was assigned female at birth } \\
\text { but has a male gender identity }\end{array}$} & $\mathrm{n}$ & 114 & 7 & 121 \\
\hline & $\%$ & $27.3 \%$ & $6.0 \%$ & \\
\hline \multirow{2}{*}{$\begin{array}{l}\text { A trans woman: a person who was assigned male at birth } \\
\text { but has a female gender identity }\end{array}$} & $\mathrm{n}$ & 172 & 13 & 185 \\
\hline & $\%$ & $41.2 \%$ & $11.1 \%$ & \\
\hline \multirow[t]{2}{*}{ Genderqueer } & $\mathrm{n}$ & 13 & 43 & 56 \\
\hline & $\%$ & $3.1 \%$ & $36.8 \%$ & \\
\hline \multirow[t]{2}{*}{ Non-binary } & $\mathrm{n}$ & 28 & 74 & 102 \\
\hline & $\%$ & $6.7 \%$ & $63.2 \%$ & \\
\hline \multirow[t]{2}{*}{ Polygender } & $\mathrm{n}$ & 1 & 12 & 13 \\
\hline & $\%$ & $0.2 \%$ & $10.3 \%$ & \\
\hline \multirow[t]{2}{*}{ Genderfluid } & $\mathrm{n}$ & 14 & 49 & 63 \\
\hline & $\%$ & $3.4 \%$ & $41.9 \%$ & \\
\hline \multirow[t]{2}{*}{ Other } & $\mathrm{n}$ & 18 & 23 & 41 \\
\hline & $\%$ & $4.3 \%$ & $19.7 \%$ & \\
\hline Total & $\mathrm{N}$ & 417 & 117 & 534 \\
\hline
\end{tabular}


a transgender past, trans woman, woman with a transgender past, crossdresser).

\subsection{Focus on Gender Non-Binary Respondents: Legal Options and Motivations to (not) Take Them}

A remarkably large group had not yet undertaken any official steps to change their name or official sex marker. Of all participants, $34.8 \%$ changed their first name and $20.2 \%$ their official sex marker. Only a small minority of the gender non-binary respondents did undertake legal steps: 10 out of 117 changed their first name (8.5\%) and 6 their sex registration (5.1\%). The survey asked those who had not undertaken these steps their reasons for not doing so. When looking at the answers from the gender non-binary group (see Table 2), we see that the most chosen answer was that they did not fulfil the requirements of the law, did not agree with the provisions of the law, and/or did not think such a step to be necessary.

Respondents choosing the option 'other reason' could give an open answer. Many of the latter referred to the lack of a 'gender fluid' or 'other' option in the legal system, and the lack of any need to register the birth sex marker on identity cards. As one respondent stated: "I wish that the mentioning of gender/sex would disappear for everybody. I am gender fluid and do not want any label." Another respondent had the same issues regarding the change of first name: "I do not wish this at the moment, since I do not live continuously according to my gender identity. Because I am non-binary, only a gender-neutral name would fit." These answers illustrate the impossibility of thinking about sex/gender on a linear spectrum or even a circle (in an attempt to avoid 'clear cut' extremes), rather it should be considered as a field of options in which (the lived experience of) male and female can intersect in many different ways, or be of no importance.

\subsection{Social Gender Discriminations and Their Relationship to Legal Gender}

Motivations for not changing legal sex markers were for some gender non-binary respondents also based on fear of discrimination, or for safety issues, as one gender nonbinary respondent stated:

There is only the possibility of M or F, and both aren't fully applicable to me. Maybe in the future (when I start hormonal therapy), I will change my sex registration because of safety issues, but not because I'm convinced that that's truly my gender.

Another gender non-binary respondent stated their fear of being discriminated against in all the administrative steps they had to take. Practical reasons were also mentioned for not changing the official sex marker. One respondent hints at work or sport contexts as a reason to change their gender marker:

If I go ahead and make these changes in the future, I will largely depend on my work situation and new pros and cons. Since I do not wish any gender reassignment surgery, and want to participate in individual sport competitions, the mention of $F$ on my identity card would at least involve that I'll need to explain every time that I am biologically speaking an $\mathrm{M}$, so as not to commit any competition forgery.

Respondents often felt left in an administrative muddle when administrative systems are based on the state registry number of the person, which indicates being assigned male or female at birth by using even or uneven numbers. Many communication templates use forms of address according to this registered sex.

Table 2. Reasons for not changing the registration of gender for gender non-binary respondents (multiple answers possible).

\begin{tabular}{lccc}
\hline & Amount & Percentage & Percentage of respondents \\
\hline I don't want to & 19 & $8.6 \%$ & $17.1 \%$ \\
I don't think it's necessary & 30 & $13.6 \%$ & $27.0 \%$ \\
I do not agree with the provisions of the law & 30 & $13.6 \%$ & $27.0 \%$ \\
I do not fulfil the requirements of the law & 32 & $14.5 \%$ & $28.8 \%$ \\
I would like to do so in the future & 28 & $12.7 \%$ & $25.2 \%$ \\
I don't know if I can & 13 & $5.9 \%$ & $11.7 \%$ \\
I find the procedure too difficult & 10 & $4.5 \%$ & $9.0 \%$ \\
I find the procedure too expensive & 9 & $4.1 \%$ & $8.1 \%$ \\
Not applicable & 13 & $5.9 \%$ & $11.7 \%$ \\
My application was rejected & 1 & $0.5 \%$ & $0.9 \%$ \\
Other & 36 & $16.3 \%$ & $32.4 \%$ \\
Total & 221 & $100 \%$ & $199.1 \%$
\end{tabular}


For gender non-binary respondents, finding their position in the gender identity field was a difficult road to travel. As one respondent explained, not having markers in society to identify with and the lack of options other than being male or female, causes serious internal stress: "Before I found myself as a non-binary trans woman, I often thought I was mad. That I was a 'crook' who was confused and had convinced themselves she was someone she was not for real." Thoughts like these and experiences with discrimination lead to high levels of emotional stress and suicidal ideation. Many reported avoidance behaviour, with $46.7 \%$ avoiding expressing their gender through physical appearance and clothing and $43 \%$ avoiding certain places or locations, both for fear of being assaulted, threatened, or harassed because of their gender identity or expression (Motmans et al., 2017, p. 72).

All in all, the voices from gender non-binary respondents were either asking for a third gender option, or for the abolishment of gender registration altogether. Some feared that introducing a third option would even lead to more stigma as long as institutions such as schools and workplaces are binary structured-and thinkingenvironments. The need for awareness-raising was underscored by many respondents.

\subsection{Lessons to Draw from the Experiences of Gender Non-Binary Respondents}

The multitude in gender experiences and gender labelling as presented by the trans respondents in this survey are indicative of the inherent impossibility of neatly covering gender diversity in clear cut categories, especially if they are but few. We also noticed the small number of people who had changed their first name and legal gender marker. These findings raise the question of whether satisfactory systems can ever be put in place to register such a complex understanding of gender. It is not always an easy task for researchers to capture gender diverse experiences and analyse them, let alone for governments to register them. Also, as the ruling by the Constitutional Court implies, the state will allow citizens to change their gender marker repetitively through a simple administrative procedure based on self-declaration. While this procedure allows for the capturing of gender fluidity, it also shows the difficulty of capturing fluidity in a rather static register.

\section{Conclusions}

Belgium is just one of many states confronted with the obligation to put into practice the right to have one's gender identity recognised and to be identified and treated in accordance with it. In this article, we examined how the Belgian state is struggling with the recognition of gender diversity whilst clinging to an existing sex registration system. We explained how the 2017 trans law, replacing its 2007 predecessor, shows a decrease of the inherent cisgender heteronormativity and stereotypical conceptualisations of sex and gender. We underscored how the 2007 trans law was merely based on sex and ignored gender, and the 2017 trans law asks for gender as a proxy to register sex. Indeed, it is no longer the physical traits and their adherence to a specific binary standard that define sex. What counts for the definition of the official sex marker on the birth certificate and what sets the door open for a change of first name is what individuals experience as their gender identity. The trans law of 2017 makes it much easier for trans people to adjust their gender registration, without any medical certificates or statements. In this sense, the trans law of 2017 has certainly been a major step forward in accommodating the legal needs of trans people. The data from the state register from 2018-2019 confirm this as they show a large increase of citizens registering a new gender marker, with half the number of changes recorded in one year being equal to the total throughout the 25 previous years.

However, while the 2017 trans law recognizes a larger group of trans persons than its predecessor, it nonetheless confirms that the traditional man/woman divide dominates the public sphere and much of social life. The individual life experiences reported in an anonymous survey amongst trans respondents in Belgium (Motmans et al., 2017) show how a lack of legal provision impacts mental well-being and avoidance behaviour, as well as the preferences of gender non-binary respondents. Indeed, at least one out of four respondents within the trans group do not identify with male or female labels. Despite the trans law of 2017, these gender non-binary respondents are still stuck in a situation in which it is impossible for them to register their gender identity. The gender non-binary respondents also report different motivations such as safety issues and the fear of discrimination for not registering with a third option, should it be available. This ties in with research by Nisar (2018) who found that a third option has limitations in a patriarchal socio-legal order where important benefits associated with the masculine identity are forfeited by registering. Nisar (2018) cautioned against overemphasizing the symbolic value of legal recognition for gender-nonconforming groups. In that sense, just adding a third legal option to an existing system without changing the dualistic structures of regulations and other institutions would be nothing more than lip service to the trans community.

Whereas gender fluidity will be accommodated for, in that citizens will be able to repeatedly change from male to female to male (or vice versa) using a simple administrative procedure, this so far remains within the male/female divide. At the same time, the procedure does not allow one to only change their first name and not their sex marker, or vice versa. Although these are two separate procedures and one is not a prerequisite for the other, civil servants tend to assume applicants will fulfil both procedures. This leads to situations where one may be refused a name 'that belongs to the other 
gender' if one is transparent about plans to not change the gender marker.

The respondents in our survey acknowledge that no system could provide an exhaustive list of types of gender identities. Some, therefore, hint at abolishing the registration of sex altogether. The ruling of the Constitutional Court makes this option available to the government. As abolishing sex registration presents a major shift in the sex/gender paradigm underlying the Belgian state and society, adding a third option might be the easiest route. The limited public opinion data available (European Commission, 2019) seem to support this option, but decent public opinion data on abolishing sex registration is absent and warrants further research. Abolishing sex registration would certainly stir debate, not the least between those eager to highlight gender discrimination relying on official data, and those arguing for alternative ways of measuring. A possible pitfall of such debate is who counts as which gender, and which measures should be applied in surveys and censuses (Brown, Herman, \& Park, 2017; Motmans et al., 2020). These issues for discussion are similar to the case of ethnicity where standard measures are needed which aim for stability and present the respondent with relatively crude fixed categories (see for instance Burton, Nandi, \& Platt, 2010). Alternative models in which sex is registered at a later age by the individual themselves, and/or in which a disconnection is installed between registering sex on the one hand and registering gender identity on the other (as discussed in Cannoot, 2019c) could provide a typical Belgian compromise, although these will require further reflection.

\section{Acknowledgments}

We are very grateful to the academic editors of this issue for their constructive comments and supportive attitude, especially during spring and summer 2020.

\section{Conflict of Interests}

The authors declare no conflict of interests.

\section{References}

Arcelus, J., \& Bouman, W. P. (2017). Language and terminology. In W. P. Bouman \& J. Arcelus (Eds.), The transgender handbook: A guide for transgender people, their families and professionals (pp. 1-12). New York, NY: Nova.

Belgian Chamber of Representatives. (2016). Verslag namens de Commissie voor de Justitie, uitgebracht door mevr. Karine Lalieux [Report on behalf of the Commission for the Justice, issued by Mrs. Karine Lalieux] (DOC 542403/004). Brussels: Belgian Chamber of Representatives. Retrieved from https://www.dekamer.be/doc/FLWB/pdf/54/2403/ 54K2403004.pdf
Belgian Official Journal. (2014). Wet houdende de vaststelling van de afstamming van de meemoeder [Law establishing the parentage of the co-mother] (C-2014/09353). Brussels: Belgian Official Journal. Retrieved from http://www.ejustice.just.fgov.be/eli/ wet/2014/05/05/2014009353/justel

Belgian Official Journal. (2007). Wet betreffende de transseksualiteit [The law of 10 May 2007 on transsexualism] (S-C-2007/09570). Brussels: Belgian Official Journal. Retrieved from https://www. ejustice.just.fgov.be/cgi_loi/change_lg.pl?language= nI\&la=N\&table_name $=$ wet $\& \mathrm{cn}=2007051055$

Belgian Official Journal. (2017a). Wet tot hervorming van regelingen inzake transgenders wat de vermelding van een aanpassing van de registratie van het geslacht in de akten van de burgerlijke stand en de gevolgen hiervan betreft [Law on the reform of regulations on transgender people as regards the indication of an adjustment of the registration of sex in the civil status records and its consequences] (C-2017/12964). Brussels: Belgian Official Journal. Retrieved from http://www.ejustice.just.fgov.be/eli/ wet/2017/06/25/2017012964/staatsblad

Belgian Official Journal. (2017b). Omzendbrief over de wet van 25 juni 2017 tot hervorming van regelingen inzake transgenders wat de vermelding van een aanpassing van de registratie van het geslacht in de akten van de burgerlijke stand en de gevolgen hiervan betreft [Circular on the law of 25 June 2017 reforming regulations for transgender people with regard to the mention of an adjustment of the registration of sex in the civil status records and its consequences] (C-2017/31879). Brussels: Belgian Official Journal. Retrieved from http://www.ejustice. just.fgov.be/cgi_loi/change_lg.pl?language=nl\&la= $N \& c n=2017121509 \&$ table_name=wet

Belgian Official Journal. (2020). Uittreksel uit arrest $n r$. 99/2019 van 19 juni 2019. Rolnummer 6813. In zake : het beroep tot gedeeltelijke vernietiging van de wet van 25 juni 2017 tot hervorming van regelingen inzake transgenders wat de vermelding van een aanpassing van de registratie van het geslacht in de akten van de burgerlijke stand en de gevolgen hiervan betreft, ingesteld door de vzw "Çavaria " en anderen [Extract from judgment no. 99/2019 of 19 June 2019. Case number 6813. With regard to: the action for partial annulment of the law of 25 June 2017 reforming regulations concerning transgender people with regard to the mention of an adjustment of the registration of gender in Regarding civil status certificates and their consequences, instituted by the non-profit association «Çavaria» and others] (No. 2019/203077). Brussels: Belgian Official Journal. Retrieved from http://www.ejustice.just. fgov.be/mopdf/2020/01/21_1.pdf\#Page10

Bouman, W. P., Schwend, A. S., Motmans, J., Smiley, A., Safer, J. D., Deutsch, M. B., . . . Winter, S. (2017). Language and trans health. International Jour- 
nal of Transgenderism, 18(1), 1-6. https://doi.org/ 10.1080/15532739.2016.1262127

Brown, T. N. T., Herman, J. L., \& Park, A. S. (2017). Exploring international priorities \& best practices for collecting data on gender minorities. Los Angeles, CA: The Williams Institute.

Burton, J., Nandi, A., \& Platt, L. (2010). Measuring ethnicity: Challenges and opportunities for survey research. Ethnic and Racial Studies, 33(8), 1332-1349. https:// doi.org/10.1080/01419870903527801

Cannoot, P. (2019a). De knuppel in het genderhok: Op weg naar $M / V / X$ in de Nederlandse geslachtsregistratie? [The bat in the gender loft: On the way to $\mathrm{M} / \mathrm{V} / \mathrm{X}$ in the Dutch gender registry?]. Tijdschrift Voor Familierecht, 2019(2), 47-54.

Cannoot, P. (2019b). Grondwettelijk Hof wil wettelijke ruimte voor genderdiversiteit [Constitutional Court wants legal space for gender diversity]. De Juristenkrant, 392, 1-3. Retrieved from http://hdl.handle. net/1854/LU-8621438

Cannoot, P. (2019c). The right to personal autonomy regarding sex (characteristics), gender (identity and/or expression) and sexual orientation: Towards an inclusive legal system. Ghent: Ghent University.

Christine Goodwin v. the United Kingdom, 28957/95 C.F.R. (11 July 2002). Retrieved from https:// hudoc.echr.coe.int/fre\#\{\%22itemid\%22:[\%2200160596\%22]\}

Defreyne, J., Motmans, J., \& T’Sjoen, G. (2017). Healthcare costs and quality of life outcomes following gender affirming surgery in trans men: A review. Expert Review of Pharmacoeconomics \& Outcomes Research, 17(6), 543-556. https://doi.org/10.1080/ 14737167.2017.1388164

Eeckhout, B., \& Paternotte, D. (2011). A paradise for LGBT rights? The paradox of Belgium. Journal of Homosexuality, 58(8), 1058-1084. https://doi.org/ 10.1080/00918369.2011.598414

European Commission. (2019). Eurobarometer on the social acceptance of LGBTI people in the EU. European Commission. Retrieved from https://bit.ly/3jzgegz

Hines, S. (2009). A pathway to diversity?: Human rights, citizenship and the politics of transgender. Contemporary Politics, 15(1), 87-102. https://doi.org/ 10.1080/13569770802674238

Junes, T. (2018). Çavaria naar Grondwettelijk Hof voor optimalisering transgenderwet [Çavaria to Constitutional Court for optimization of transgender law]. Zizo. Retrieved from https://bit.ly/2R3gJUh

Meier, P. (2009). E comme émancipation, égalité et éthique: La société belge en évolution [ $E$ as emancipation, equality and ethics: The Belgian society in evolution]. In J. Beaufays \& G. Matagne (Eds.), La Belgique en mutation: Systèmes politiques et politiques publiques (1968-2008) [Belgium in mutation: Political systems and public politics (1968-2008)] (pp. 253-283). Brussels: Bruylant.

Motmans, J. (2011). 'We can't have men giving birth!' (but we do). The impact of the Belgian transgender movement on the well being of transgender persons in Belgium. In A. E. Woodward, J.-M. Bonvin, \& M Renom (Eds.), Transforming gendered well-being in Europe: The impact of social movements. Surrey: Ashgate Publishing.

Motmans, J., Burgwal, A., \& Dierckx, M. (2020). Adviesnota: Het meten van genderidentiteit in kwatitatief onderzoek [Advisory note: Measuring gender identity in quantitative research]. Ghent: Ghent University.

Motmans, J., de Biolley, I., \& Debunne, S. (2010). Being transgender in Belgium: Mapping the social and legal situation of transgender people. Brussels: Institute for the Equality of Women and Men.

Motmans, J., Nieder, T. O., \& Bouman, W. P. (2019). Transforming the paradigm of nonbinary transgender health: A field in transition. International Journal of Transgenderism, 20(2/3), 119-125. https://doi.org/ 10.1080/15532739.2019.1640514

Motmans, J., Wyverkens, E., \& Defreyne, J. (2017). Being transgender in Belgium: Ten years later. Brussel: Institute for the Equality of Women and Men.

Nisar, M. A. (2018). (Un)Becoming a man: Legal consciousness of the third gender category in Pakistan. Gender \& Society, 32(1), 59-81. https://doi.org/ 10.1177/0891243217740097

Parliamentary Assembly. (1989). Condition of transsexuals (Recommendation 1117 [1989]). Strasbourg: Council of Europe. Retrieved from https:// assembly.coe.int/nw/xml/XRef/Xref-XML2HTMLen.asp?fileid $=15151$ \&lang=en

Parliamentary Assembly. (2015). Discrimination against transgender people in Europe (Resolution 2048 [2015]). Strasbourg: Council of Europe. Retrieved from https://assembly.coe.int/nw/xml/XRef/XrefXML2HTML-EN.asp?fileid $=21736$

Senaeve, P., \& Uytterhoeven, K. (Eds.). (2008). De rechtspositie van de transseksueel. Commentaar op de wetten van 9 en 10 mei 2007 en van 15 mei 2007 [The legal position of the transsexual: Commentary on the Laws of May 9 and 10, 2007 and May 15, 2007]. Antwerpen: Insertia.

Van Caenegem, E., Wierckx, K., Elaut, E., Buysse, A., Dewaele, A., Van Nieuwerburgh, F., . . . T'Sjoen, G. (2015). Prevalence of gender nonconformity in Flanders, Belgium. Archives of Sexual Behavior, 44(5), 1281-1287. https://doi.org/10.1007/s10508014-0452-6

Van Hove, H. (2019). Transgender personen in België die een wijziging van de officiële geslachtsvermelding aanvragen-Gegevens uit het Rijksregister (1 januari 1993 t.e.m. 30 september 2019) [Transgender persons in Belgium requesting a change of the official gender identification: Data from the National Register (1 January 1993 to 30 September 2019)]. Brussels: Instituut voor de Gelijkheid van Vrouwen en Mannen. Retrieved from https://igvm-iefh.belgium.be/ 
$\mathrm{nl} /$ publicaties/transgender_personen_in_belgi_ gegevens_uit_het_rijksregister

Verschelden, G. (2018). Vernietigingsberoepen tegen de Transgenderwet: aanloop naar of valkuil voor de nonbinaire genderoptie? [Annulment appeals against the Transgender Act: Run-up to or pitfall for the nonbinary gender option?]. Tijdschrift Voor Familierecht, 2018(3), 66-68.

Verschelden, G. (2020). Deel II. Aanpassing van de geslachtsregistratie: voorwarden, gevolgen, privacy en overgangsrecht [Part II. Adjustment of gender registration: Conditions, consequences, privacy and transitional law]. In J. Motmans \& G. Verschelden (Eds.), De rechtspositie van transgenderpersonen in België. Een multidisciplinaire analyse na de wetten van 25 juni 2017 en 18 juni 2018 [The legal position of transgender people in Belgium: A multidisciplinary analysis after the laws of June 25, 2017 and June 18, 2018] (Vol. 20, pp. 35-121). Antwerpen and Cambridge: Intersentia.

World Professional Association for Transgender Health on Identity Recognition. (2015). WPATH identity recognition statement. WPATH. Retrieved from https://www.wpath.org/media/cms/Documents/ Web\%20Transfer/Policies/WPATH\%20Identity\% 20Recognition\%20Statement\%2011.15.17.pdf

Zhang, Q., Goodman, M., Adams, N., Corneil, T., Hashemi, L., Kreukels, B., . . Coleman, E. (2020). Epidemiological considerations in transgender health: A systematic review with focus on higher quality data. International Journal of Transgender Health, 21(2), 125-137. https://doi.org/10.1080/26895269. 2020.1753136

\section{About the Authors}
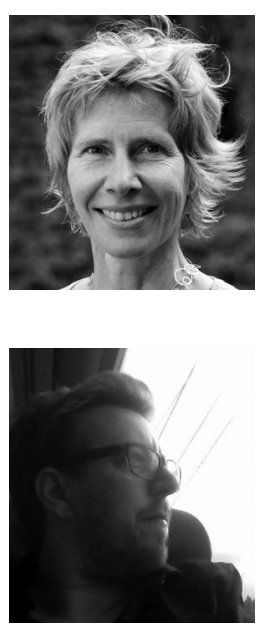

Petra Meier is Professor in Politics, University of Antwerp, Belgium, specialized in the (re)presentation of gender in politics and policies, and mechanisms (re)producing inequality. Recent publications focus on: the importance of symbolic representation; the flipside of role models in politics; the relation between demos, gender, and democracy; the relation between demos and demoi in multi-level systems; the multiple relations between gender and power in the European Parliament; and how institutionalized feminism struggles with expertise and intersectionality.

Joz Motmans is Guest Professor in Gender Studies, Ghent University, Belgium, specialized in gender and sexuality. He is also the Coordinator of the Central Information and Knowledge Centre on Trans Issues in Belgium (www.transinfo.be) at the Centre of Sexology and Gender at the Ghent University Hospital, Belgium. His expertise includes novel LGBTIQ social movements, equality policy, discrimination and violence, mental wellbeing, social and sexual health, and quality of life. 